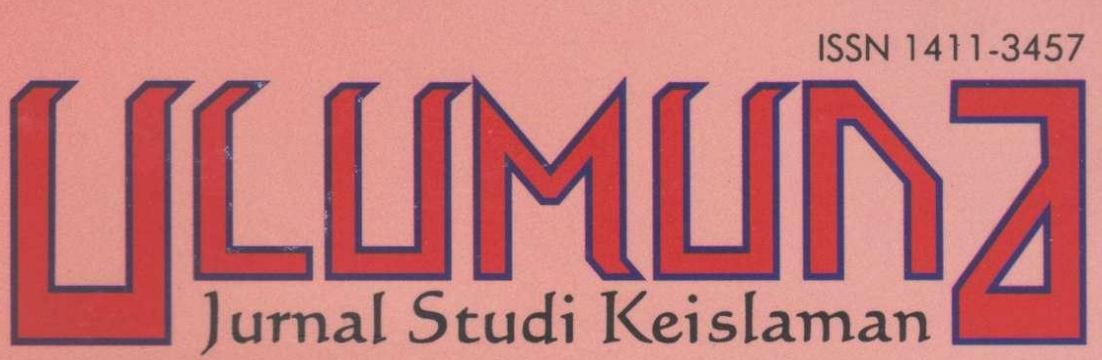
Volume XIV• Nomor 1• Juni 2010

TERAKREDITASI Berdasarkan SK Dirjen Dikti Depdiknas Nomor: 65a/DIKTL/Kep/2008

FILSAFAT ISLAM: ANTARA DUPLIKASI DAN KREASI Abdullah Satar

AL-HIKMAH AL-MUTA'ÂLIYAH: PEMIKIRAN METAFISIKA EKSISTENSIALISTIK MULLA SHADRA Sholihan

HERMENEUTIKA AL-QUR'AN: ANTARA PEMAKNAAN TEKSTUAL DAN KONTEKSTUAL Slamet Mulyono R

MENIMBANG KEMBALI PARADIGMA FILSAFAT ISLAM DALAM BANGUNAN KEILMUAN ISLAM KONTEMPORER Aksin Wijaya

KONTRIBUSI FILSAFAT ILMU DALAM STUDI ILMU AGAMA ISLAM: TELAAH PENDEKATAN FENOMENOLOGI Mulyadi

SIGNIFIKANSI TEORI POPPER, KUHN, DAN LAKATOS TERHADAP PENGEMBANGAN ILMU-ILMU KEISLAMAN Ahmad Choirul Rofiq 
TransLiterasi

Artikel

Abdullah Sattar

Sholihan

Suhermanto Ja'far

Abdul Mukti Ro'uf

Aksin Wijaya

Mulyadi

Slamet Muliono R. Hermeneutika Al-Qur'an:

Antara Pemaknaan Tekstual

dan Kontekstual • 101-120

Menimbang Kembali Paradigma Filsafat

Islam dalam Bangunan Keilmuan Islam

Kontemporer $\bullet 121-144$

Konstribusi Filsafat Ilmu dalam

Studi Ilmu Agama Islam: Telaah

Pendekatan Fenomenologi • 145-176

Ahmad Choirul Rofiq Signifikansi Teori Popper, Kuhn, dan

Lakatos terhadap Pengembangan

Ilmu-Ilmu Keislaman • 177-196

Win Usuluddin

Elusidasi Filosofis Kebhinekaan

Keagamaan: Refleksi atas Pluralisme

Keberagamaan Era Postmodern • 197-226

\section{INDEKS}




\section{PEDOMAN TRANSLITERASI}

\begin{tabular}{|c|c|c|c|c|c|}
\hline Arab & & Latin & Arab & & Latin \\
\hline 1 & $=$ & $\mathrm{a}$ & ف & $=$ & $\mathrm{f}$ \\
\hline ب & $=$ & b & ق & $=$ & $q$ \\
\hline ت & $=$ & $\mathrm{t}$ & ك5 & $=$ & $\mathrm{k}$ \\
\hline$\dot{H}$ & $=$ & ts & J & $=$ & 1 \\
\hline ج & $=$ & j & 5 & $=$ & $\mathrm{m}$ \\
\hline$\tau$ & $=$ & $\underline{\mathrm{h}}$ & ن ن & $=$ & $\mathrm{n}$ \\
\hline$\dot{\tau}$ & $=$ & $\mathrm{kh}$ & و & $=$ & $\mathrm{w}$ \\
\hline د & $=$ & $\mathrm{d}$ & 。 & $=$ & $\mathrm{h}$ \\
\hline ذ & $=$ & $\mathrm{d} z$ & $\Leftrightarrow$ & $=$ & , \\
\hline J & $=$ & $\mathrm{r}$ & ي & $=$ & $\mathrm{y}$ \\
\hline j & $=$ & z & & & \\
\hline س & $=$ & $\mathrm{s}$ & & & \\
\hline ش & $=$ & sy & \multirow{2}{*}{\multicolumn{3}{|c|}{$\begin{array}{l}\text { Untuk Madd } \\
\text { dan Diftong }\end{array}$}} \\
\hline ص ص & $=$ & sh & & & \\
\hline ض ض & $=$ & $\mathrm{dl}$ & i & $=$ & â (a panjang) \\
\hline b & $=$ & th & إي - اي & $=$ & $\hat{1}$ (i panjang) \\
\hline ظ & $=$ & $\mathrm{zh}$ & أو - أو & $=$ & û (u panjang) \\
\hline$\varepsilon$ & $=$ & ' & او - - او & $=$ & aw \\
\hline$\dot{\varepsilon}$ & $=$ & gh & أي اي & $=$ & ay \\
\hline
\end{tabular}




\title{
KONTRIBUSI FILSAFAT ILMU \\ DALAM STUDI ILMU AGAMA ISLAM: \\ TELAAH PENDEKATAN FENOMENOLOGI
}

Mulyadi*

\begin{abstract}
Islamic studies is considered both religious and scientific activities. As scientific activities it needs to establish its scientific bases through the study of philosophy of science. From the perspective of philosophy of science, almost all types of knowledge experience what is called a shifting of paradigm. Islamic studies is not exception, so that changes, re-formulations, and improvement of its epistemological design and construction are very possible. Thus, Islamic studies are not static, but dynamic. It always faces current challenges of changing times and styles that are always experienced by Muslims and human being in general. This means that Islamic studies that used to apply purely normative and empirical approaches to phenomena of buman religiosity should shift to phenomenological one. The approach is worth to broaden insights and open new borizons in search for the essence and the fundamental structure of human religiousity.
\end{abstract}

Abstrak: Studi ilmu agama Islam dipandang sebagai kegiatan keagamaan dan keilmuan sekaligus. Ketika dipandang sebagai kegiatan keilmuan, maka ia perlu memapankan pondasi keilmiahannya melalui telaah filsafat ilmu. Menurut filsafat ilmu, hampir semua jenis ilmu pengetahuan, mengalami apa yang disebut dengan shifting of paradigm. Studi ilmu agama Islam bukan pengecualian, sehingga sangat mungkin terjadi perubahan, perumusan kembali, dan penyempurnaan terhadap rancang bangun epistemologi keilmuannya. Dengan demikian, studi ilmu agama Islam sebenarnya tidak bersifat statis, tetapi dinamis. Ia selalu menghadapi tantangan-tantangan terkini dari perubahan zaman yang selalu dialami oleb kaum muslimin dan umat manusia pada umumnya. Itu berarti bahwa studi ilmu agama Islam yang dabulunya melulu bersifat normatif dan empiris terhadap fenomena keberagamaan manusia perlu beranjak ke arah pendekatan yang lebih bersifat fenomenologis. Pendekatan itu bermakna untuk memperluas wawasan dan membuka cakrawala baru dalam mencari esensi dan struktur dasat keberagamaan manusia.

Keywords: Filsafat Ilmu, Ontologi, Epistemologi, Aksiologi, Studi Ilmu agama Islam.

*Penulis adalah dosen pada Fakultas Psikologi UIN Maulana Malik Ibrahim Malang. email: rif_an91@yahoo.com. 
DI KALANGAN para ulama masih terdapat perdebatan di sekitar permasalahan apakah studi ilmu agama Islam dapat dimasukkan dalam bidang ilmu pengetahuan, mengingat sifat dan karakteristik antara ilmu pengetahuan dan agama berbeda. Pembahasan sekitar permasalahan ini banyak dikemukakan oleh para pemikir Islam belakangan ini. M. Amin Abdullah, misalnya, mengatakan bahwa pangkal tolak kesulitan pengembangan wilayah studi ilmu agama Islam berakar pada kesukaran para ulama untuk membedakan antara yang normativitas dan historisitas. Pada dataran normativitas studi ilmu agama Islam agaknya masih banyak terbebani oleh misi keagamaan yang bersifat memihak, romantis, dan apologis sehingga kadar muatan analisis kritis, metodologis, historis, dan empiris terutama dalam menelaah teks-teks atau naskah keagamaan produk sejarah terdahulu kurang ditonjolkan, kecuali dalam lingkungan para peneliti tertentu yang masih sangat terbatas.

Secara sederhana dapat ditemukan jawabannya bahwa dilihat dari segi normatif sebagaimana yang terdapat dalam al-Qur'an dan hadis, Islam lebih merupakan agama yang tidak dapat diberlakukan kepadanya paradigma ilmu pengetahuan, yaitu paradigma analisis kritis, metodologis, historis dan empiris. Sebagai agama, Islam lebih bersifat memihak, romantis, apologis, dan subjektif, sedangkan jika dilihat dari segi historis, yakni Islam dalam arti yang dipraktekkan oleh manusia serta tumbuh dan berkembang dalam sejarah kehidupan manusia, Islam dapat dikatakan sebagai sebuah disiplin ilmu, yakni ilmu agama Islam.

Perbedaan dalam melihat Islam yang demikian itu dapat menimbulkan perbedaan dalam menjelaskan Islam itu sendiri. Ketika Islam dilihat dari segi normatif, maka Islam merupakan agama yang di dalamnya berisi tentang ajaran Tuhan yang berkaitan dengan urusan akidah dan mu'amalah. Ketika Islam dilihat dari sudut historis atau sebagaimana yang nampak dalam masyarakat, maka Islam tampil sebagai sebuah disiplin ilmu.

Studi ilmu agama Islam adalah kegiatan keilmuan, untuk tidak mengatakan hanya sebagai kegiatan keagamaan. Jika studi ilmu agama Islam masuk dalam wilayah keilmuan, telaah filsafat ilmu terhadap bangunan atau rancangan bangunan keilmuan studi ilmu agama Islam perlu dipertimbangkan. Menurut telaah 
filsafat ilmu, hampir semua jenis kegiatan ilmu pengetahuan, baik natural sciences maupun social sciences, bahkan religious sciences, selalu mengalami apa yang disebut dengan shifting paradigm (pergeseran gugusan pemikiran keilmuan). Kegiatan ilmu pengetahuan selamanya bersifat historis, lantaran dibangun, dirancang, dan dirumuskan oleh akal budi manusia yang juga bersifat historisitas, dalam arti terikat oleh ruang dan waktu, terpengaruh oleh perkembangan pemikiran dan perkembangan kehidupan sosial yang mengitari penggal waktu-waktu tertentu. Dengan begitu, sangat dimungkinkan terjadinya perubahan, pergeseran, perbaikan, perumusan kembali, serta penyempurnaan rancang bangun epistemologi keilmuan. Jika tidak demikian, kegiatan keilmuan akan stagnasi dengan sendirinya atau bersifat statis. Studi ilmu agama Islam dalam artian kegiatan keilmuan sangatlah kaya nuansa sehingga dimungkinkan untuk dapat diubah, dikembangkan, diperbaiki, dirumuskan kembali, dan disempurnakan sesuai dengan semangat zaman yang mengitarinya. Dengan demikian, studi ilmu agama Islam sebenarnya tidak bersifat statis, tetapi bersifat dinamis, sesuai dengan arus dan corak tantangan perubahan zaman yang selalu dialami oleh manusia muslim itu sendiri.

Kemungkinan terjadinya shifting paradigm dalam wilayah studi ilmu agama Islam sebenarnya tidak perlu terlalu dikhawatirkan lantaran inti pemikiran ilmu agama Islam dalam berporos pada tauhid dan bermoralitas al-Qur'an akan tetap seperti apa adanya. Hanya saja rumusan-rumusan baru dan pendekatan-pendekatan kontemporer diupayakan mengingat perubahan cara berfikir manusia era teknologi modern tidaklah sama dan sebangun dengan cara dan pola berfikir manusia era pra-scientific agrarian. Setidaknya bahasa dan pola berfikir yang digunakan harus disesuaikan dengan muatan pengalaman manusia modern era ilmu dan teknologi, tanpa harus meninggalkan warisan khazanah intelektual Islam klasik. Jika ini tidak dilakukan, diskursus studi ilmu agama Islam akan tertinggal dari laju pertumbuhan cara berfikir manusia muslim pendukungnya dan paling tidak akan terjadi gap antara keberagamaan dan kehidupan itu sendiri.

Dengan terjadinya pergeseran paradigma (shifting paradigm) dalam wilayah studi ilmu agama Islam dari pendekatan yang 
melulu bersifat normatif dan empiris terhadap fenomena keberagamaan manusia ke arah pendekatan yang lebih bersifat fenomenologis juga perlu ditelusuri. Mencermati tata kerja pendekatan fenomenologi, orang sulit menghindari kesan adanya pengaruh filsafat ilmu terhadap pendekatan fenomenologi. Pendekatan ini sangat berjasa dalam membuka wawasan dan cakrawala baru dalam mencari esensi keberagamaan manusia. ${ }^{1}$

\section{Filsafat Ilmu dalam Pandangan Filosof Muslim}

Filsafat ilmu adalah bagian dari epistemologi yang secara khusus mengkaji hakekat ilmu (pengetahuan ilmiah). Ia merupakan telaah falsafi yang ingin menjawab tiga pertanyaan penting mengenai hakekat ilmu, yang meliputi objek apa yang ditelaah ilmu, bagaimana wujud hakiki dari objek tersebut, bagaimana prosedur perolehan ilmunya, dan untuk apa pengetahuan itu dipergunakan?

Dua pertanyaan pertama disebut landasan ontologis, pertanyaan ketiga landasan epistemologis, dan pertanyaan keempat adalah aksiologis. Tiga kelompok pertanyaan tersebut adalah sesuatu yang pokok dan ciri dalam sebuah keilmuan atau menjadi penyangga bagi eksistensi ilmu. ${ }^{2}$ Tanpa mengenai ciri pengetahuan ini dengan benar, seseorang tidak bakal dapat memanfaatkannya secara maksimal, bahkan justru dapat menjadikan seseorang salah dalam menggunakannya. Sedemikian, sehingga ilmu terkacaukan dengan seni, ilmu terkonfrontasikan dengan keyakinan agama dan seterusnya.

\section{Problem Ontologi.}

Objek kajian ilmu adalah segala yang ada, yang terjangkau oleh pengetahuan dan pengalaman manusia. ${ }^{3}$ Apa hakekat yang

${ }^{1}$ Mircea Eliade, The Sacred and The Profane: The Nature of Religion, ter. Willard R. Trask (Harcourt: Brace \& World Inc., t.t.), 232.

${ }^{2}$ Koento Wibisono Siswomihardjo, Ilmu Pengetahuan Sebuah Sketsa Umum Mengenai Kelabiran dan Perkembangannya sebagai Pengantar untuk Memahami Filsafat Umum (Makalah disajikan pada Internship Filsafat Ilmu Pengetahuan Universitas Gadjahmada Yogyakarta bulan Januari 1997), 12.

3Jujun S. Suriasumantri membatasi kajian ilmu pada masalah ini, yang dapat dicapai oleh pengalaman manusia, yang itu sangat empiris. Menurutnya, ilmu tidak dapat menggapai sesuatu yang ghaib dan rohani. 
ada (what is being)? Inilah yang menjadi kajian filsafat ilmu. Para filosof terpecah dalam berbagai aliran dalam menjawab persoalan ini. Harold $H$. Titus, dosen filsafat dari Denion University, USA, menjelaskan pendapat kelompok-kelompok tersebut dalam bukunya Persoalan-persoalan Filsafat, ${ }^{4}$ yang secara garis besar dapat dibagi menjadi tiga kelompok pemikiran: monisme, dualisme, dan pluralisme.

Menurut monisme, hakekat yang ada adalah satu; tidak ada perbedaan antara yang spirit dengan yang materi, antara substansi dan aksidensi. Perbedaan yang ada di antara keduanya hanyalah karena adanya proses yang berbeda, substansinya tetap sama. Ibarat zat dan energi, energi hanya bentuk lain dari zat. ${ }^{5}$ Kelompok monisme ini terdiri atas dua kelompok: materialisme dan idealisme.

Menurut materialisme, ${ }^{6}$ yang menjadi hakekat dan babak terakhir segala sesuatu adalah materi sebab segala yang bersifat material senantiasa menempati ruang tertentu, yang itu berarti juga bersangkutan dengan waktu. Seseorang tidak dapat mempunyai pendirian tentang materi, kecuali sebagai satuan yang berkesinambungan yang dinamis, yang mengalami proses serta perubahan. Suatu proses tanpa berkaitan dengan ruang dan waktu adalah suatu pengertian yang tidak dapat dimengerti. Prinsip-prinsip pemikiran materialisme ini pertama kali dikembangkan oleh Democritos (460-370 SM).

Sebagian lain, yang dikenal dengan golongan idealisme, ${ }^{7}$ menyatakan bahwa hakekat segala sesuatu adalah ide, jiwa atau spirit. Menurut mereka, apa yang disampaikan kaum materialis memang telah memberi keterangan mengenai kenyataan. Akan tetapi, harus disadari bahwa di antara fenomena benar-benar ada yang tidak dapat dijelaskan lewat pengertian alam atau materi. Pengalaman, nilai, makna, dan sejenisnya adalah sesuatu yang

Lihat Jujun S. Suriasumantri, Filsafat Ilmu: Sebuab Pengantar Populer (Jakarta: Sinar Harapan, 2006), 91.

${ }^{4}$ Lihat Harold H. Titus, Persoalan-Persoalan Filsafat, ter. H.M. Rasjidi (Jakarta: Bulan Bintang, 1984), 291-410.

${ }^{5}$ Suriasumantri, Filsafat ..., 66.

${ }^{6}$ Louis O. Kattsoff, Pengantar Filsafat, ter. Soejono Soemargono (Yogyakarta: Tiara Wacana, 1996), 220-23.

${ }^{7}$ Ibid., 224-7. 
tidak dapat dijelaskan dengan istilah-istilah materi. Pengalaman adalah sesuatu yang dipunyai jiwa; nilai hanya bermakna jika ada jiwa yang dapat memahami, dan hanya jiwa yang dapat menangkap makna. Dengan demikian, menurut kelompok ini, roh atau jiwa adalah sesuatu yang hakiki dari yang ada (being). Dalam sejarahnya, pemikiran ini dicetuskan oleh Plato (427-347 SM), dan saat ini dipelopori oleh antara lain Watts Cunningham, Wilbur Urban, dan William E. Hacking.

Menurut kelompok dualisme, apa yang ada (being) tersusun atas dua hal sekaligus: substansi dan aksidensi, spirit dan materi. Dua hal tersebut berbeda sui generic secara substantif, tetapi menyatu membentuk yang ada. Menurut Suriasumantri, ${ }^{8}$ filosof yang menganut faham ini antara lain Rene Descartes (15961650), John Locke (1632-1714), dan George Berkeley (16851753). Dalam Islam seringkali dapat disebut, misalnya, 'Ayn al Qudlat al-Hamadânî (1098-1131). ${ }^{\text {Hat }}$

Menurut kaum pluralisme atau bylomorfisme, yang ada tidak hanya satu atau dua, tetapi sebanyak apa yang tampak itu sendiri. Tidak ada satu pun dari yang materi, yang ragawi dan inderawi, yang tidak merupakan kesatuan esensi dan eksistensi, yang itu merupakan hakekat dari sesuatu itu sendiri. Dengan demikian, hakekat segala yang ada adalah masing-masing yang ada itu sendiri dan masing-masing mempunyai hakekat dan ciri sendirisendiri.

Bagaimana persoalan ini menurut pandangan kebanyakan filosof muslim? Menurut al-Farâbî (870-950), apa yang ada tidak hanya satu, tapi banyak. Akan tetapi, kebanyakan ini tidak sama dengan apa yang dipahami kaum pluralis atau dualis, antara yang satu sama lainnya saling terpisah atau bertentangan. Sifat kebanyakan pada yang ada di sini bersifat hierarki tingkat kesempurnaan. ${ }^{10}$ Menurut Al-Farâbî, ada enam kerangka yang

${ }^{8}$ Suriasumantri, Filsafat ..., 68.

${ }^{9}$ Lihat Al- Hamadânî, Tabmidât (Teheran: Publications de I'Universite de Teheran, 1962).

${ }^{10}$ Lihat Osman Bakar, Classification of Knowledge in Islam, a Study in Islamic Philosophies of Science (Kuala Lumpur: Institute for Policy Research, 1992), 117-9. Lebih jelasnya, lihat al-Farâbî, “Al-Siyâsah al-Madâniyyah”, dalam Rasâil (Haiderabat: Dâr al-Ma'ârif al-'Utsmînî, 1345 H). 
menjadi inti dan penyusun yang ada, yang urutan secara menurun adalah sebab pertama (al-sabab al-awwal), sebab kedua (al-sabab al-tsânî), intelek aktif (al-'aql al-fa'al), jiwa (nafs), bentuk (shûrah), dan materi (mâddah). ${ }^{11}$

Pemikiran senada juga diberikan oleh kalangan sufisme. Menurut mereka, dengan mendasarkan gagasannya pada keterangan yang diberikan al-Qur'an, seluruh yang ini terdiri atas lima hierarki realitas yang diformulasikan dalam doktrin "lima keberadaan ilahiyah" (al-badhârât al-ilâhiyyah al-khams). ${ }^{12}$ Realitas pertama sekaligus realitas yang paling rendah adalah alam materi, alam nyata, atau yang dikenal dengan istilah alam nâsut. Hierarki ini tidak hanya meliputi segala apa yang tampak di bumi, tetapi juga mencakup segala yang tampak di langit: matahari, bintang, planet-planet, dan semua yang kasat mata. Realitas kedua yang satu tingkat lebih halus dibanding alam materi adalah alam malakut atau alam psikis, alam kejiwaan. Selanjutnya, realitas ketiga adalah alam jabarût atau alam ruh.

Dalam hubungan strukturalnya, alam materi yang disebut alam kasar diliputi dan didominasi wilayah psikis, yang disebut juga alam halus, yang berada di atasnya. Keduanya secara bersama-sama membentuk wilayah "alam" yang semua bentuk hukumnya diatur oleh alam jabarût. Selanjutnya, hierarki realitas yang lebih tinggi adalah "asmâ' sifâtiyyah", alam sifat-sifat Ilahiyah. Misalnya, sifat-sifat yang merujuk kepada-Nya sebagai Sang Maha Pencipta dan Sang Pemberi Wahyu. Hierarki keempat ini, yang juga disebut "lahût", dapat dipersamakan dengan-meminjam istilah Osman Bakar "Prinsip Kreatif atau Wujud", yaitu prinsip ontologis dari keseluruhan kosmos. Karena itu, ia merupakan Yang Absolut terhadap seluruh ciptaan. Puncak segala realitas adalah esensi ilahi (Dzat ilahiyah). "Keadaan" tertinggi yang juga diistilahkan sebagai "bâhût" (berasal dari kata "Huwa" yang berarti Dia) ini adalah Diri, Wujud, atau Realitas Tertinggi yang tidak terbatas. Realitas tidak

11 A. Khudori Soleh, Pandangan Filosof Muslim terhadap Filsafat Ilmu (Makalah, t.t.).

${ }^{12}$ Osman Bakar, Tawhid and Science, Essays on the History and Philosophy of Islamic Science (Malaysia: Secretariat for Islamic Philosophy and Science, 1991), 32-3. 
tergapai. Dia adalah Prinsip "tidak dapat disifati” dan "tidak dapat ditentukan" sehingga Absolut Murni.

Ada perbedaan-atau bahkan mungkin kemajuan-ontologi yang cukup tajam antara para pemikir muslim dengan rivalnya di Barat. Bagi para filosof muslim, meski sama-sama sejauh pengalaman manusiawi, batas objek kajian ilmu tidak terbatas pada yang "indrawi" atau "jiwa", tetapi telah melangkah lebih dari itu, bahkan pada yang ada di "sekitar" Tuhan sendiri. Pengalaman yang mereka capai tidak hanya terbatas pada yang "indrawi", tetapi "ruhani" dalam makna yang sebenarnya. Perbedaan ontologi ini, pada gilirannya akan menyebabkan perbedaan pada epistemologi dan aksiologi; karena selain pada pengalaman, filosof muslim juga mendasarkan diri pada nashnash agama.

\section{Problem Epistemologi}

Bagaimana cara menyusun pengetahuan yang benar? Inilah kajian falsafi yang disebut epistemologi; prosedur menyusun pengetahuan yang benar sesuai dengan metode-metode ilmiah. Maksudnya, pengetahuan yang disusun dan dihasilkan tersebut benar-benar rasional, teruji, dan diandalkan. ${ }^{13}$ Sarana yang digunakan untuk itu adalah bahasa dan aturan logis, cara berpikir menurut aturan-aturan tertentu sehingga tercapai kesimpulan tertentu pula. ${ }^{14}$

Ada beberapa macam metode ilmiah yang dapat digunakan dalam masalah ini. Pertama, induktif, yakni penalaran dari semua contoh yang ada menuju generalisasi. ${ }^{15}$ Persoalan yang dihadapi penalaran induksi adalah tentang banyaknya kasus yang harus diamati untuk dapat sampai pada kesimpulan yang bersifat umum. Akan tetapi, karena berdasarkan pengalaman dan indera, metode "hasil" ini lebih nyata dan pasti. Meskipun demikian, David Home ${ }^{16}$ mengkritik bahwa model penalaran induksi

${ }^{13}$ Suriasumantri, Filsafat..., 120.

${ }^{14}$ Lebih jauh uraian tentang aturan-aturan logis ini, lihat Ver Haak dan Haryono Imam, Filsafat Ilmu Pengetahuan Telaah atas Cara Kerja Ilmu-ilmu (Jakarta: Gramedia, 1997), 17-26.

${ }^{15}$ Lebih jelas tentang ini, lihat Kenneth T. Gallagher (Hartono Hadi), Epistemologi Filsafat Pengetahuan (Yogyakarta: Kanisius, 1987), 135.

16Kenneth T. Gallagher, Epistemologi..., 136-9. 
terlalu jauh untuk dibuat generalisasinya karena kenyataan selalu bersifat partikular. Penalaran induksi umumnya banyak digunakan oleh kaum empirisme, yakni kelompok pemikir (filosof) yang menggunakan indera dan pengalaman sebagai sarana untuk mencapai kebenaran. ${ }^{17}$

Dalam hubungannya dengan pengetahuan, menurut John Locke (1632-1704), bapak empirisme Inggris, hanya dapat diperoleh lewat indera dan pengalaman. Menurutnya, manusia lahir dalam keadaan seperti kertas kosong (tabularasa) dan di situlah ditulis pengalaman-pengalaman inderawi. Fungsi akal hanya ibarat tempat penampungan, yang secara pasif menerima hasil-hasil penginderaan tersebut. Dengan demikian, semua pengetahuan yang bagaimana pun rumitnya dapat dilacak kembali pada pengalaman-pengalaman inderawi yang pertamatama, yang dapat diibaratkan sebagai atom-atom penyusun objek material. Apa yang tidak dapat atau tidak perlu dilacak kembali secara demikian bukanlah pengetahuan. Setidaknya bukan pengetahuan mengenai hal-hal yang faktual.

Sebelumnya, pendapat seperti ini telah diberikan oleh Aristoteles (384-322 SM), yang dianggap sebagai peletak dasar prinsip aliran empirisme. Menurutnya, berbeda dengan pendapat gurunya, Plato (427-347 SM), apa yang ada bukanlah yang berada di dalam otak, di dalam pikiran, tetapi pada benda-benda yang konkret. Di luar itu semua, tidak ada apa pun, hanya sebutan saja, bukan benda sesungguhnya sekalipun yang dimaksud adalah benda yang ghaib. Apa yang ada di dalam pikiran, termasuk pengetahuan, adalah semata hasil dari apa yang ditangkap indera. ${ }^{18}$

Penalaran induksi di atas juga digunakan oleh kelompok positivisme. Menurut Auguste Comte (1798-1857), pendiri aliran ini, pengetahuan adalah apa yang didasarkan atas pengalaman objektif yang faktual dan positif. Aliran ini benar-benar mendasarkan diri pada sesuatu yang nyata, pasti, dan objektif sehingga mereka menolak metafisika. ${ }^{19}$ Perbedaan mereka

${ }^{17}$ Tentang para tokoh empirisme, lihat Harun Hadiwijono, Sari Sejarah Filsafat Barat II (Yogyakarta: Kanisius, 1997), 31-5.

${ }^{18}$ Ibid., 48.

${ }^{19}$ Ibid., 109-10. 
dengan kelompok empirisme adalah bahwa positivisme hanya membatasi diri pada pengalaman objektif, sedangkan empirisme kadang-kadang masih menerima juga pengalaman batiniyah atau pengalaman-pengalaman subjektif. Mereka inilah barangkali yang dimaksud, atau setidaknya dapat dimasukkan dalam aliran yang oleh Kattsoff 20 diistilahkan dengan "empirisme radikal". Menurut Kattsoff, kelompok empirisme radikal menganggap bahwa semua pengetahuan "harus" dapat dilacak sampai pada pengalaman inderawi; yang tidak dapat dilacak secara otomatis tidak dianggap sebagai pengetahuan.

Kedua, deduktif, yakni penalaran dari yang umum atau yang sudah diketahui sebelumnya untuk mengkaji partikular. Penalaran model ini memberikan sifat rasional kepada pengetahuan dan bersifat konsisten dengan pengetahuan yang telah dikumpulkan sebelumnya. Secara sistematik, pengetahuan disusun dan setahap demi setahap melalui argumentasi yang mapan sehingga pengetahuan yang tersusun menjadi tubuh pengetahuan yang terorganisasi dengan baik, runtut, dan dapat dipertanggungjawabkan secara logika dan ilmiah. Ilmu menjelaskan secara rsional dan konsisten terhadap objek yang berada dalam fokus telaahan atau kajian. ${ }^{21}$

Dalam pelaksanaannya, penalaran model ini umumnya banyak digunakan oleh kaum rasionalisme, suatu kelompok pemikiran yang menganggap bahwa sumber ilmu pengetahuan adalah akal; meskipun tidak mengingkari pentingnya pengalaman, pengalaman dipandang sebagi jenis perangsang pikiran. Dengan demikian, benar sesatnya sebuah pengetahuan sangat dipengaruhi dan ada di dalam ide, bukan pada kenyataan atau objek. ${ }^{22}$

Aliran rasionalisme muncul pada abad renaisance yang dipelopori oleh Rene Descartes (1596-1650), Blaise Pascal (1923-1662), dan Baruch Spinoza (1632-1677), tetapi prinsip-

${ }^{20}$ Kattsoff, Pengantar..., 137.

${ }^{21}$ Penggunaan metode deduksi secara mudah digunakan dalam ilmu-ilmu pasti. Lebih jauh tentang masalah ini, lihat Ver Haak, Filsafat..., 81 dan seterusnya. Lihat pula, Berling, dkk., Pengantar Filsafat Ilmu (Yogyakarta: Tiara Wacana, 1997), 23-50.

${ }^{22}$ Kattsoff, Pengantar..., 139. 
prinsip dasarnya telah diletakkan oleh Plato (437-247 SM). Menurut Plato, sebelum kelahirannya di dunia, manusia telah mengalami preeksistensi di dunia ide. Di sana mereka menerima bekal konsep tentang kebenaran dan kenyataan. Saat lahir, ia kenal kembali segala yang dihadapi berkat bekal-bekal ide tersebut. Bagi Plato, ${ }^{23}$ dunia hanyalah bayangan dari alam ide sehingga pengetahuan manusia pada dasarnya adalah pengenalan kembali ide-ide yang telah diperolehnya, sesuatu yang tidak dapat diragukan. Dengan demikian, akal budi dipahami sebagai (1) sejenis perantara khusus yang dengannya sebuah kebenaran dapat diketahui dan (2) teknik deduktif yang dengannya dapat dicapai sebuah kebenaran artinya dengan melakukan penalaran. Dengan metode deduktif, seorang penganut rasionalisme mengakui kebenaran-kebenaran yang dikandung oleh presmispremis yang mengantarkannya. Oleh karena itu, jika menginginkan kesimpulan tersebut berupa pengetahuan, premispremis pendukungnya harus mutlak benar, tidak boleh diragukan. Bagi Descartes, kebenaran-kebenaran apriori ini dikenal oleh sifatnya yang terang dan tegas.

Pada abad-abad berikutnya, metode induksi yang digunakan kaum empirisme dan deduksi yang ditunjukkan rasionalisme di atas rupanya dianggap belum mencukupi untuk mengungkap fenomena objek kajian pengetahuan yang sebenarnya. Lahirnya metode baru diprakarsai oleh Immanuel Kant (1724-1804), yang berusaha menggabungkan dua metode di atas sekaligus (rasionalisme kritis). Menurut Kant, rasio murni tidak mungkin mencapai pengetahuan karena pengetahuan hasil rasio bersifat analitis-apriori. Artinya, objek sudah terlebih dahulu masuk di dalam subjek sehingga tidak memberikan informasi baru meski bersifat universal. Begitu pula yang terjadi dalam empiris, ilmu hasil empiris adalah sistesis aposteori; artinya, memberi informasi baru, tetapi tidak universal sehingga perlu sistesis apriori yang oleh Koento Wibisono diistilahkan dengan "rasionalisme kritis", yang berusaha mencapai kebenaran universal sekaligus baru.

Konsep Kant ini pada gilirannya disempurnakan oleh Edmud Husserl (1859-1938) dengan istilah fenomenologi yang

23Lebih jelas lihat Hadiwijono, Sari ..., 38-45. 
pelaksanaannya melalui tiga tahap reduksi (saringan): reduksi fenomenologi, reduksi audetis, dan reduksi transendental. ${ }^{24}$ Menurut Husserl, reduksi fenomenologis adalah suatu bentuk pengamatan awal di mana objek dipandang "apa adanya", tapi penuh dengan "kecurigaan". Di sini objek dibiarkan tanpa diberi statemen dan diletakkan di dalam kesadaran. Jika berhasil, seseorang akan menemukan fenomena yang sebenarnya, mengenal gejala dalam dirinya sendiri. Setelah itu, masuk tahap kedua, reduksi aidetis, penyaringan segala sesuatu yang bukan menjadi hakekat fenomena. Masuk reduksi ketiga, transendental, mengeluarkan segala yang tidak berhubungan dengan kesadaran murni, agar dengan objek tersebut seseorang dapat mencapai dirinya sendiri. Walhasil, metode ini diterapkan pada subjek sendiri dan pada perbuatannya, pada kesadaran murninya.

Sekarang bagaimana persoalan epistemologi ini menurut para filosof muslim? Dengan hierarki ontologis sebagaimana dijelaskan di atas, para filosof muslim rupanya hampir sepakat bahwa indera dan rasio adalah sarana penting untuk menggapai pengetahuan atau kebenaran. Akan tetapi, apa yang dihasilkan dua sarana tersebut belum dapat mencapai hakiki, tetapi baru tahap mendekati; atau menurut istilah Henry Bergson (18591941), baru tahap "pengetahuan mengenai" (knowledge about) belum "pengetahuan tentang" (knowledge of). "Pengetahuan mengenai" adalah pengetahuan langsung, pengetahuan intuitif yang diperoleh simbol secara langsung. ${ }^{25}$

Menurut al-Ghazâlî (1058-1111) indera adalah sarana paling rendah dalam menggapai pengetahuan. Ia hanya mampu mengkaji apa yang tampak yang itu tidak jarang luput dari kesalahan. Sarana yang lebih tinggi di atas indera adalah akal. Dengan premis-premis dan logika, akal tidak hanya mampu memikirikan apa yang tampak, tetapi juga apa yang ada di balik yang tampak. Meskipun demikian, ia tetap terbatas, tidak benarbenar mampu menggapai yang transendental. Untuk itu, perlu sarana lain, yaitu intuisi, penyinaran langsung cahaya pengetahuan dari Yang Maha Transenden (Tuhan). Persoalannya, bagaimana seseorang mendapatkan penyinaran

\footnotetext{
${ }^{24}$ Ibid., 140.

${ }^{25}$ Kattsoff, Pengantar..., 144-5.
} 
pengetahuan langsung dari Tuhan? Menurut al-Ghazâlî dan para tokoh sufi Sunni, hal itu melalui "pengosongan diri" dengan metode "takbliyyah", "tabliyyah", dan "tajliyyah". ${ }^{26}$ Takbliyyah adalah membersihkan diri dari segala kejahatan, ketidakbenaran, dan mengkosongkan perhatian kepada makhluk atau fenomena. Tahap tabliyah mengisi diri dengan segala tindakan baik dan berkonsentrasi untuk berhubungan dengan-Nya (tawajjub) dengan kegiatan-kegiatan ritual tertentu. Tahap tajliyyah adalah suatu keadaan ketika subjek yang tersucikan siap untuk menerima pancaran cahaya pengetahuan, yang dalam tasawuf diistilahkan dengan kasyf dan ma'rifat.

Pendapat kedua yang dipelopori kaum filosof, seperti AlFarâbî, Ibn Sînâ, Suhrawardi, dan para tokoh sufisme Syi'ah justru sebaliknya, menggunakan kekuatan indera, rasio, dan kesucian hati sekaligus secara maksimal. Menurut mereka, ilmuilmu rasional dan ilmu pasti tidak dapat dikesampingkan untuk menggapai pengetahuan yang benar yang dipancarkan Tuhan. Jelasnya, epistemologi dilakukan dengan pensucian hati dan mempergunakan sarana indera dan rasio secara maksimal: observasi, eksperimen, penalaran, dan sejenisnya sehingga apa yang dilakukan mendapat bimbingan langsung dari Tuhan.

\section{Problem Aksiologi}

Setelah mendapatkan pengetahuan, untuk apa ia dipergunakan? Kemana perkembangan ilmu harus diarahkan? Inilah yang dinamakan aksiologi, kajian yang berkaitan dengan kegunaan pengetahuan yang telah diperoleh. Menghadapi persoalan ini ada dua kelompok pendapat. Pertama, ilmu bersifat netral terhadap nilai-nilai, baik atau pun buruk. ${ }^{27}$ Tugas ilmuwan adalah menemukan pengetahuan itu sendiri dan terserah orang lain untuk mempergunakannya, untuk tujuan baik atau jahat. Kedua, netralitas ilmu terhadap nilai hanya sebatas metafisika keilmuan, sedangkan dalam penggunaannya, bahkan pada

${ }^{26}$ Tentang cara bagaimana subjek menjalani takhliyyah dan tabliyyah, lihat Al-Ghazâlî, Adab fî al- Dîn (Beirut: al-Maktabah al-Sya'biyah, t.t.).

27 Tentang apa yang dimaksud baik dan buruk, lihat Kattsoff, Pengantar..., 325 dan seterusnya; Franz Magnis Susana, 13 Tokoh Etika Sejak Zaman Yunani sampai Abad ke-19 (Yogyakarta: Kanisius, 1997). 
pemilihan objek penelitian sendiri, kegiatan keilmuan harus berlandaskan asas-asas moral. Pendapat kedua ini didasarkan atas kenyataan faktual yang ada di masyarakat: (1) ilmu secara faktual cenderung, bahkan telah digunakan dengan mempergunakan teknologi keilmuan, (2) ilmu telah berkembang pesat dan main esoteric sehingga kaum ilmuwan lebih mengetahui ekses-ekses yang mungkin terjadi bila ada penyalahgunaan, dan (3) ilmu telah berkembang sedemikian pesat di mana terjadi kemungkinan bahwa ilmu mengubah manusia dan kemanusiaan yang paling hakiki, seperti pada kasus revolusi genetika, cloning, dan teknik perubahan masyarakat (social engineering). 28 Berdasarkan tiga hal tersebut, ilmu secara moral harus ditujukan untuk kebaikan manusia tanpa merendahkan martabat atau mengubah hakekat kemanusiaan.

Senada dengan itu, al-Ghazâlî membagi ilmu menjadi dua bagian: fardl 'ayn dan fardl kifâyah. ${ }^{29}$ Pembedaan tersebut didasarkan atas tingkat keutamaan dan kemanfaatannya dalam kehidupan bermasyarakat yang terus berkembang dan berubah. Ilmu-ilmu yang dalam kategori fardl 'ayn harus lebih didahulukan daripada yang fardl kifâyah karena ia lebih penting dan mendesak diketahui demi kebaikan agama dan masyarakat. Jadi, ilmu pengetahuan tidak bebas nilai, meski dalam teorinya bisa saja demikian. Ia berkaitan erat dengan soal kemanusiaan; apakah ia membawa kebaikan atau kejahatan pada manusia. Dalam hal ini kemanfaatan dan peningkatan derajat kemanusiaan harus lebih diutamakan dan didahulukan.

\section{Kontribusi Filsafat Ilmu dalam Studi ilmu agama Islam}

\section{Studi ilmu agama Islam dalam Perspektif Filsafat Ilmu}

Dalam kegiatan keilmuan, seorang ilmuwan dituntut untuk mempunyai "asumsi dasar" atau "postulasi" yang jelas yang dibangun di atas dasar pemikiran yang sistematis-metodologis. Tanpa asumsi dasar atau postulasi yang kokoh, jelas dan sistematis, analisis pemecahan persoalan yang hendak ditawarkan tidak akan tajam dan sulit mengarah pada titik fokus tujuan

28Suriasumantri, Filsafat..., 235.

${ }^{29} \mathrm{Al}-\mathrm{Ghazâlî,} \mathrm{I} \mathrm{byyâ'} \mathrm{'Ulûm} \mathrm{al-Dîn} \mathrm{I} \mathrm{(Beirut:} \mathrm{Dâr} \mathrm{al-Fikr,} \mathrm{t.t.).}$ 
tertentu yang hendak dicapai. Ibarat sebuah "kacamata baca" yang dirancang sesuai dengan ilmu-ilmu dasar optik, begitu pula "asumsi dasar" atau postulasi yang hendak dipertahankan harus dihimpun, disusun, dan dirumuskan secara matang dan sistematis sesuai dengan bidang keilmuan tertentu sehingga dapat diharapkan mempermudah mengantarkan pada sebuah analisis yang mapan dan dapat pula dipertanggungjawabkan secara akademik. Bangunan pemikiran filsafat, lebih-lebih filsafat keilmuan, sebenarnya merupakan tatanan asumsi dasar atau postulasi yang disusun secara sistematis-argumentatifdemonstratif sehingga mempunyai daya kekuatan analisis yang tajam terhadap berbagai persoalan yang hendak dipecahkan, termasuk persoalan-persoalan ilmu agama.

Agama Islam di samping sebagai ajaran juga sebagai ilmu. Sebagai ajaran, agama mengandung unsur masalah yang ghaib, adanya hubungan baik dengan kekuatan yang ghaib tersebut, respons emosional dari manusia, baik respons dalam bentuk rasa takut maupun perasaan cinta, dan adanya yang suci, seperti kitab suci dan tempat-tempat suci. Adapun agama sebagai ilmu disebut dengan ilmu agama. Ilmu agama dapat dimaknai sebagai proses, prosedur, dan produk. ${ }^{30}$ Ilmu agama sebagai proses merupakan aktivitas penelitian tentang fenomena dan ajaran agama secara rasional, kognitif, dan teologis. Ilmu agama sebagai prosedur adalah aktivitas kajian/penelitian tentang fenomena dan ajaran agama dengan menggunakan metode-metode ilmiah. Makna ilmu agama sebagai produk adalah berisi tentang kumpulan fenomena dan ajaran agama secara sistematis yang merupakan hasil aktivitas kajian/penelitian dengan menggunakan metode ilmiah. Bertitik tolak dari uraian tersebut, ilmu agama merupakan rangkaian aktivitas manusia yang rasional dan kognitif untuk mengkaji/meneliti fenomena dan ajaran agama dengan menggunakan berbagai macam metode ilmiah sehingga menghasilkan kumpulan fenomena dan ajaran agama yang sistematis untuk mencapai kebenaran, memperoleh pemahaman, atau pun melakukan penerapan.

30The Liang Gie, Pengantar Filsafat Ilmu (Yogyakarta: Liberty, 1997), 90. 
Acapkali para pakar ilmu agama mengklaim bahwa garapan mereka bukanlah teologi semata karena dalam science of religion ditonjolkan aspek pendekatan ilmiah terhadap fenomena keberagamaan manusia. Para teolog kurang simpatik terhadap pendekatan ilmiah terhadap agama karena mereka menganggap para ahli ilmu agama mereduksi agama sebagai gejala sosial semata sehingga aspek spiritualnya kurang mendapat prioritas. ${ }^{31}$ Jadi, memang ada semacam ketegangan antara kaum teolog dengan para ilmuwan agama. Barangkali atas keprihatinan ini, Mukti Ali mengajukan rumusan studi ilmu agama yang bersifat "scientific conductriner" dengan harapan dapat menjembatani adanya ketegangan tersebut. Tanpa aspek doktrin, agama akan kehilangan nuansa dan ciri khas yang mewarnainya. Sudah barang tentu, banyak jasa ilmu agama ini dalam mengendorkan konflik teologis antara penganut agama-agama di Indonesia.

Terlepas dari jasa tersebut, perlunya perubahan wawasan studi ilmu agama yang bercorak positvistik ke humanistikhermeneutik agaknya semakin menonjolkan sosoknya. Dalam bidang yang paling dekat dengan kulit positivisme sendiri, yakni ilmu pengetahuan agama ternyata faktor subjektivitas manusia dan kesejarahannya perlu tetap diakui keabsahannya. Bukan hanya aspek logikanya yang terpokok, tetapi juga aspek subjektivitas-kesejarahan manusianya juga perlu digarisbawahi.

Thomas Kuhn, sebagai orang yang menekuni sejarah ilmu pengetahuan, mengemukakan temuannya bahwa antara satu teori ilmu pengetahuan, seperti teori fisika Aristoteles sulit sekali untuk dapat dibandingkan dengan teori Newton. Demikian pula, sulit untuk dibandingkan teori Newton dengan teori kuantum mekanikanya Einsten. Masing-masing punya ciri khas sehingga sulit untuk dicari titik temu dari segi objektivitas dan keuniversalannya. Bukan segi keuniversalannya dan keobjektifan ilmu pengetahuan yang ditekankan di situ, tetapi yang ditonjolkan adalah kenyataan bahwa teori ilmu pengetahuan yang satu dapat dikoreksi oleh teori ilmu pengetahuan yang

${ }^{31}$ A. Mukti Ali, dkk., Penelitian Agama di Indonesia (Jakarta: Sinar Harapan, 1982), 23. 
lain. ${ }^{32}$ Konsep sentral Kuhn ialah paradigma. Menurutnya, ilmu yang sudah matang dikuasai oleh suatu paradigma tunggal. 33 Paradigma ini membimbing kegiatan ilmiah dalam masa ilmu normal, di mana ilmuwan berkesempatan menjabarkan dan mengembangkan paradigma secara rinci dan mendalam, karena tidak disibukkan dengan hal-hal yang mendasar. Dalam kondisi krisis, paradigma mulai diperiksa dan dipertanyakan. Untuk mengatasi krisis itu ilmuwan dapat mengembangkan suatu paradigma tandingan yang dapat memecahkan masalah dan membimbing riset berikutnya. Jika itu terjadi, itulah revolusi ilmiah. Dalam revolusi ini terjadi proses peralihan komunitas ilmiah dari paradigma lama ke paradigma baru.

Dengan munculnya Kuhn, ide commensurability menjadi kurang relevan. Kita perlu mencari model lain yang lebih tepat untuk mendekati suatu persoalan. Jika tidak, kita akan terjebak pada paradigma yang kita kira sangat layak, tetapi pada kenyataannya meleset sama sekali. Adanya normal science dan revolutionary science sangat memberi insipirasi pada generasi ilmuwan berikutnya untuk merumuskan kembali paradigma metodologi penelitiannya. Ternyata adagium yang dilontarkan oleh golongan positivist bahwa "nothing new under the sun" sangat bergantung pada faktor subjektivitas, sejarah, dan kreativitas manusia dalam menatap tatanan kehidupan masyarakat dan alam yang sudah mapan. Harold I. Brown malah menandaskan bahwa "any creative act is a rational". 34

Jalan masuk yang disumbangkan oleh filsafat ilmu kemudian diperlebar dan diperkeras oleh Jurgen Habermas, tidak boleh dibayangkan adanya kesamaan titian jalan yang mereka lalui. Mereka mempunyai cara pendekatan kritis-filosofis yang berbeda dalam melihat persoalan aktual manusia. Titik kesamaan pandangan mereka hanya terletak pada kesempatan bahwa metode pemikiran dan penelitian filsafat yang bersifat

32 Thomas Kuhn, The Structure of Scientific Revolution (Chicago: The University of Chicago Press, 1976), 134.

${ }^{33}$ C. Ver Haak, S.J. dan Hariyono Imam, Filsafat Ilmu Pengetahuan: Telaah atas Kerja Ilmu-Ilmu (Jakarta: PT. Gramedia, 1999), 165.

${ }^{34}$ Harold I. Brown, Perception, Theory and Commitment, the New of Philosophy Science (Chicago: The University of Chicago Press, 1972), 13. 
positivistik tidaklah tepat untuk mengkaji persoalan manusia yang kompleks.

Kritik Habermas tidak lain adalah kritik terhadap saintisme dan positivisme yang sudah berubah menjadi "ideologi". Menurutnya, saintisme dan positivisme sudah menjadi ideologi yang tertutup, lantaran ideologi ini berpegang teguh pada hukum yang positif-objektif, baik dalam ekonomi, sejarah, dan sosial sehingga tidak fleksibel lagi dan tidak kondusif untuk melakukan "paradigm shift" dalam menatap realitas struktur sosial yang ada. Hukum social, seperti survival for the fittes yang berlaku di banyak bidang kehidupan, dianggap memang begitu adanya sehingga mempengaruhi struktur kehidupan sosial ekonomi dalam masyarakat luas. Hukum tersebut dianggap objektif, universal, dan perlu berlaku di mana-mana. Yang mempertanyakan validitas dan objektivitas teori malah dituduh tidak ilmiah.

Keyakinan yang dipegang teguh oleh para ilmuwan hampir dari segala cabang ilmu pengetahuan ini paralel saja dengan keyakinan para filosof terhadap teori "form' atau "idea" Plato yang objektif, permanen, transenden, perlu, dan universal, yang terlepas dari proses kesejarahan manusia. Ini mirip dengan transendentalisme Kant yang bersifat "necessary dan universal', atau roh absolut Hegel yang mengacu kepada masyarakat yang rasional, atau positivisme Marx yang tidak mengenal fleksibilitas hukum sejarah untuk mengubah nasib kaum proletar. Ada semacam keyakinan bahwa esensi yang dicari-cari oleh para filosof atau hukum-hukum alam dan sosial yang dicari-cari oleh para ilmuwan, jika sudah ditemukan, tidak dapat berubah dan memang tidak perlu diubah-ubah untuk disesuaikan dengan kebutuhan manusia. Jika masih dapat diubah-ubah, hal itu tidak objektif lagi, tidak ilmiah, tidak transcendental, dan tidak universal.

Ternyata penonjolan secara tajam tuntutan dan sikap objektif, positif, exact, dan lugas tanpa disadari membawa serta kecenderungan yang menepikan sikap subjektif, sikap yang memihak. Ilmu-ilmu menjadi netral dan kurang peduli dengan perkembangan masyarakat modern yang semakin teralienasi dari masyarakat sekitar dan lingkungannya. Karena kenetralannya itu, mereka merasa risih dan tidak terpanggil untuk melihat 
bangunan struktur masyarakat yang tidak adil. Hal demikian dianggap di luar bidang garap mereka. Dengan begitu, semacam ada keputusan antara ilmu sebagai profesi dan tanggung jawab sosial dan lingkungan para pencetusnya.

Pertautan antara metafisika dan etika, antara teori dan praktis memang hendak digalakkan kembali oleh para filosof sekarang ini. Ilmu pengetahuan yang melaju pesat tanpa keterkaitan moral untuk memihak kepada alam lingkungan dan golongan manusia yang lemah agaknya memang ada something wrong dalam dasar logika, epistemologi, maupun ontologinya. Mekanisme kerja yang mempertautkan kembali antara keduanya sedang dicari-cari modus operandinya. Metafisika yang cenderung hanya berkehidupan kontemplatif, terlepas dari kepedulian sosial dan lingkungan alam sekitar agaknya memang tidak banyak bermanfaat untuk kehidupan secara utuh dan global atas bumi yang semakin sempit ini.

Masih jarang para filosof yang mengkaji pertautan antara metafisika dan etika. Karl Apel Otto dan Emmanuel Levinas, untuk menyebut beberapa, juga Soedjatmoko, mencoba mendalami dan memecahkan masalah itu. Jika memang ke arah sana titik temu keprihatinan yang dicita-citakan pemikiran filosofis, hal itu agaknya paralel saja dengan apa yang digarap oleh studi ilmu agama, meskipun yang terakhir ini belum lagi memunculkan konsep yang menggigit juga dalam hal etika pemihaknya. ${ }^{35}$

Jika diteliti lebih mendalam, ternyata historisitas kemanusiaan yang mengitari pencetus pemikiran studi ilmu agama Islam saat awal mula terbentuknya ikut mewarnai bentuk rancang bangun keilmuan studi ilmu agama Islam yang berkembang saat ini. Dengan kata lain, kondisi sosial, budaya, terlebih-lebih lagi politik mewarnai bentuk paradigma studi ilmu agama Islam termasuk di dalamnya keilmuan kalam. ${ }^{36}$ Namun, keikutsertaan dan campur tangan historisitas kemanusiaan pada era dan waktu tertentu dalam perumusan rancang bangun epistemologi suatu

35 M. Amin Abdullah, Studi Agama, Normativitas atau Historisitas (Yogyakarta: Pustaka Pelajar, 1996) 92.

36Fazlur Rahman, Membuka Pintu Ijtihad, ter. Anas Mahyudin (Bandung: Pustaka, 1984), 38. 
ilmu, terlebih-lebih lagi dalam hal yang menyangkut paradigma ilmu-ilmu agama, sangat dihindari bahkan kadang sangat terasa ditutup-tutupi. Jangankan pada ilmu-ilmu agama yang menyangkut totalitas kehidupan manusia (ultimate concern), dalam ilmu-ilmu kealaman (natural sciences) pun dimensi historisitas kemanusiaan dan subjektivitas ilmuwan banyak tidak disukai oleh sementara kalangan ilmuwan. Ilmuwan yang yakin akan kebenaran berpikir logik-positivistik lebih menekankan sisi "objektivitas" ilmu daripada sisi "subjektivitas"-nya; lebih menggarisbawahi peran logika dan bukannya proses panjang kesejarahan penemuannya. ${ }^{37}$

Menurut filsafat ilmu, hampir semua jenis kegiatan ilmu pengetahuan, baik natural science, social science, maupun religious science (ilmu agama) selalu mengalami apa yang disebut dengan shifting paradigm (pergeseran gugus pemikiran keilmuan). Kegiatan ilmu pengetahuan selamanya bersifat historis lantaran dibangun, dirancang, dan dirumuskan oleh akal budi manusia yang juga bersifat historis, yaitu terikat oleh ruang dan waktu, terpengaruh oleh perkembangan pemikiran dan perkembangan kehidupan sosial sesuai dengan perubahan zaman. Dalam studi ilmu agama, aturannya juga berlaku apa yang diistilahkan oleh Thomas Kuhn dengan normal science dan revolutionary science. Perubahan shifting paradigm dari wilayah normal science ke wilayah revolutionary science akan memperkokoh keberadaan studi ilmu agama Islam yang sesuai dengan perkembangan ilmu pengetahuan dan teknologi serta perkembangan zaman.

Dalam ilmu pengetahuan yang sepositif, selogis dan seobjektif apa pun, ternyata keterlibatan dan campur tangan historisitas kesejarahan manusia sangat mempengaruhi tatanan dan rancang bangun epistemologi ilmu pengetahuan. Justru karena historisitas yang selalu berubah-ubah, kesalahan, ketidaktetapan, dan anomali-anomali yang terdapat dalam rumusan ilmu pengetahuan generasi sebelumnya dapat dimungkinkan untuk dikoreksi dan dibenahi kembali oleh

${ }^{37}$ Thomas Skluen, The Essential Tension: Selected Studies in Scientific Tradition and Change (Chicago: The University of Chicago Press, 1977), 224. 
generasi ilmuwan yang datang berikutnya untuk mendekati kebenaran dan gambaran realitas yang sebenarnya. ${ }^{38}$

\section{Pendekatan Fenomenologi dalam Studi ilmu agama Islam}

Gambaran fenomena manusia beragama sebenarnya tidaklah semudah dan sesederhana seperti yang biasa dibayangkan oleh banyak orang. Ada manfaatnya memang untuk melihat agama dalam bentuknya yang tidak sederhana, lantaran berbagai persoalan pelik yang terkait dengan fenomena itu sendiri. Untuk mengurangi beban kesulitan persoalan studi ilmu agama, pendekatan fenomenologi agama adalah sangat penting. Fenomenologi sebenarnya lahir sebagai reaksi atas positivisme dan saintisme. ${ }^{39}$ Pendekatan fenomenologi ini melengkapi pendekatan antropologi terhadap fenomena keberagamaan manusia. Pendekatan antropologi menyerupai pendekatan dalam wilayah applied science, sedangkan pendekatan fenomenologi dalam studi ilmu agama menyerupai pendekatan dalam wilayah pure science dalam diskursus keilmuan secara umum. Keduaduanya, yakni pendekatan fenomenologi dan antropologi terhadap studi ilmu agama, seperti halnya hubungan antara pure science dan applied science adalah saling mengisi, melengkapi, memperkokoh, dan mengkritik kekurangan yang melekat pada masing-masing pendekatan tersebut.

Pendekatan fenomenologi adalah suatu bentuk pendekatan keilmuan yang berusaha mencari hakekat atau esensi dari apa yang ada di balik segala macam bentuk manifestasi agama dalam kehidupan manusia di muka bumi. Dalam perkembangan selanjutnya, terjadi perbedaan-perbedaan mengenai fenomenologi, khususnya fenomenologi dalam studi ilmu agama yang disebut fenomenologi agama, semakin marak. Dalam tulisan ini penulis hanya menjelaskan sebagian atau beberapa model fenomenologi agama.

Dasar Epistemologi Fenomenologi. Fenomenologi dalam arti luas adalah sebuah aliran dalam sejarah filsafat kontemporer yang dasar-dasarnya diletakkan oleh Edmund Husserl. Dalam arti

${ }^{38}$ Abdullah, Studi..., 91.

${ }^{39}$ K. Bertens dan A.A. Nugroho, Panorama Filsafat Modern (Jakarta: Penerbit PT. Gramedia, 1987), 50. 
sempit, fenomenologi adalah sebuah epistemologi yang pada akhirnya kembali kepada sesuatu yang sifatnya idealistis, lebih banyak menggunakan intuisi untuk mencapai pengetahuan. Fenomenologi lahir sebagai reaksi terhadap materialisme, positivisme, rasionalisme, dan saintisme. Fenomenologi ingin mengangkat ilmu-ilmu dalam kubu humaniora, seperti sejarah, bahasa, sastra, seni, dan agama sebagai suatu ilmu yang dapat memenuhi kebutuhan manusia.

Dalam mempelajari fenomenologi, ada beberapa kata kunci yang harus dipahami, yaitu istilah fenomenon, observasi, kesadaran, dan substansi. Adapun dasar epistemologi fenomenologi adalah: (1) fenomenologi adalah sebuah epistemologi (metode berfikir) dengan cara terlebih dahulu subjek harus membebaskan diri dari tradisi, prasangka subjektivitas atau pengalaman yang mendahului; (2) objek harus disaring melalui suatu reduksi (ephoce) dan apa yang direduksikan itu disimpan; artinya, tidak mengambil kesimpulan dari apa yang direduksikan; (3) objek dipandang secara rohani dengan suatu intuisi melalui tiga macam reduksi, yaitu reduksi fenomenon, reduksi eideti, dan reduksi transendental. ${ }^{40}$

Reduksi fenomenon adalah gejala yang menampakkan pada objek dengan penuh kesadaran dan penuh kewaspadaan kita awasi dan dalam hal ini hasil pengawasan kita batin, kita tidak menyampaikan hal-hal apa pun mengenai hal faktual tadi. Misalnya, rumah, secara reduksi fakta ini tidak menyatakan mengenai bentuknya, mengenai di mana letaknya, karena kita ingin mengetahui dari dalam. Tujuan reduksi fenomenal adalah menemukan gejala yang sesungguhnya. Reduksi eiditis berasal dari kata eidos (hakekat). Dalam tahapan ini semua yang sifatnya accidental (ada 9 jenis, antara lain ruang, waktu, wujud, dan kedudukan) yang telah hakiki kita letakkan dalam kurung; tujuannya untuk mencari struktur dasar, atau sesuatu yang esensial. Reduksi transendental, akhirnya gejala yang merupakan data/fakta, dicoba untuk diletakkan sebagai suatu data yang lagilagi tersimpan dalam kurung untuk kemudian direduksi terakhir, yaitu transidental. Di sini semua pengetahuan apriori kita

40Hadiwijono, Sari..., 140. 
lepaskan. Di saat ini kita kembali ke diri sendiri, aku empirik dilepaskan secara sadar; yang tertinggal adalah kesadaran monokesadaran transidental untuk mencapai (erlebaisse). Di sinilah terjadi suatu kondisi ketika subjek mengalami diri sendiri; aku transidental merupakan tempat untuk mengkonstitusikan pengetahuan. Sesuatu yang dicari adalah sesuatu yang substansif, yaitu kesesuaian antara objek yang diamati secara rohani dengan sesuatu yang maknawi atau sesuatu yang evident.

Fenomenologi Model Edmun Husserl. Husserl (1859-1939) dipandang sebagai pencipta 41 fenomenologi agama pada pandangan yang membiarkan ungkapan-ungkapan pengalaman keagamaan berbicara untuk dirinya sendiri daripada memaksanya untuk ke dalam suatu bagan yang telah ditetapkan sebelumnya untuk menjaga dan melindungi sifat yang sebenarnya. Menurut Husserl, ada tiga beban tugas fenomenologi agama: (1) mencari hakekat ketuhanan, (2) menjelaskan teori wahyu, dan (3) meneliti tingkah laku keagamaan. ${ }^{42}$ Prinsip utama fenomenologi Husserl adalah epoche dan eidetic vitian. Ephoce (pemberian tanda kurung) penundaan penilaian di pihak pengamatan terhadap kebenaran, nilai, dan eksistensi dari suatu fenomena. Eidetic vitian mengungkap fenomena melalui empati dan intuisi. Prinsip ephoce dan eidetic vitian selanjutnya dikembangkan oleh banyak sarjana seperti Vander Leew dan C.J. Bleker.

Fenomenologi Model Waardenburgh. Waardenburgh seorang fenomenolog Belanda, dalam makalahnya Reflection and the Study of Religion membagi aliran fenomenologi agama menjadi lima macam (1) pengkalisifikasian terhadap fenomena keagamaan dan tradisi keagamaan yang berbeda, (2) pencarian terhadap motif atau ide dasar dalam berbagai tradisi keagamaan, (3) pendefinisian fenomena keagamaan dalam suatu struktur fundamental yang asli, (4) pembahasan dan pengetahuan terhadap fenomena keagamaan sesuai dengan struktur dasar manusia, dan (5) interpretasi sejarah keagamaan manusia dalam

${ }^{41}$ Waardenburgh, Reflection on the Study of Religion: Dalam Metodologi Studi Agama, ter. Ahmad Norma Permata (Yogyakarta: Pustaka Pelajar, 2001), 379 .

42Ibid., 379-80. 
perkembangannya berdasarkan waktu. 43 Mencari makna fenomena keagamaan, menurut Waardenburgh, dapat melalui beberapa cara, seperti keagamaan yang ada dalam dirinya, struktur ideal atau konsep tentang agama dan pengalaman keagamaan sebagai esensi realitas keagamaan tersebut menggambarkan fenomena keagamaan tidak berdasarkan rasional ketat dan refleksi filosofis keras. Waardenburgh secara kuat menekankan kepada pengalaman keagamaan atau sensivitas si pengkaji agama, dan menganggap intuisi langsung si peneliti sebagai salah satu bagian metodologis. Intuisi ini harus mampu menembus kepada apa yang diyakini sebagai sisi irrasional dari pengalaman keagamaan, sebagai dasar terdalam dalam agama itu sendiri. 44

Fenomenologi Model H. Biezais. Fenomenologi intuitif Husserl maupun Waardenburgh dianggap tidak memadai lagi dalam menganalisis fenomena keagamaan. H. Biezais menawarkan fenomenologi tipologi dalam makalahnya Typology of Religion and the Phenomenological Method. ${ }^{45} \mathrm{H}$. Biezais memperkenalkan pendekatan fenomenologis bersifat satu sisi dan bersifat abstrak. Ia menawarkan tiga tipe fenomenologis tipologis dalam tiga bentuk: pertama, tipe yang secara empiris didasarkan kepada fakta-fakta yang dikaji dalam sejarah agama, kedua, tipe sebagai abstrak, prinsip-prinsip normatif sistematis berdasarkan persamaan atau perbedaan dari berbagai sifat fenomena yang bersangkutan, ketiga, melalui fenomenologi tipe-tipe dapat mengembangkan hubungan antara objek yang dipahami dan orang yang memahaminya, antara ruang empiris dan transendental. Menurut Hiezair metode fenomenologis tipologis dapat menyingkap makna kontekstual. Prinsip ephoce dan eidetic vitian yang menghasilkan fenomenologi intuitif dan tipologis dikritik oleh W.H. Oxtoby bahwa prinsip tersebut tidak kritis dan tidak

43 Joachim Wach, Ilmu Perbandingan Agama, ter. Djainonnuri (Jakarta: Rajawali, 1984), 35.

${ }^{44}$ Waardenburgh, Reflection..., 303.

${ }^{45}$ Makalah H. Biezais tersebut dibawa oleh L. Honko dalam Science of Religion: Studies in Methodology dalam konferensi IAHR di Turki pada tahun 1973, 143-161. 
objektif. Menurutnya epoche menunda kritis dan eidetic vitian menunda objektivitas. ${ }^{46}$

Fenomenologi Model C.J. Blekeer. C.J. Blekeer, seorang fenomenolog Belanda, dimasukkan dalam fenomenolog modern bersama Van Der Leew. Ia mendasarkan teorinya pada epoche eidetic vitian Husserl yang bersifat figurative dan menajamkan analisisnya dengan teori Van Der Leew, terutama dalam penelitian kritis logos. Blekeer merumuskan tujuan fenomenologi dalam tiga macam: pertama, theoria yang mengungkap makna fenomena keagamaan, kedua, logos fenomena yang menembus ke dalam struktur berbagai bentuk kehidupan keagamaan, dan ketiga, entlectia dari fenomena yang merupakan jalan di mana suatu esensi menampakkan diri dalam dinamika perkembangan kehidupan umat manusia. ${ }^{47}$

Makalah Blekeer berjudul The Contribution of Phenomenology of Religion in the Study in the History of Religion 48 membedakan fenomenologi dalam tiga macam: pertama, fenomenologi aliran deskriptif yang berurusan dengan sistematisasi fenomena keagamaan, kedua, fenomenologis tipologis yang bertujuan melakukan pencarian tentang esensi, makna, dan struktur fenomena keagamaan. Bleeker sendiri memposisikan dirinya pada bagian ketiga, meskipun ia sendiri sebenarnya meyakini tipologi.

Bleeker memulai pembahasan fenomenologi dari pembahasan tentang fenomenologi sebagai metode dan fenomenologi sebagai disiplin ilmu agama yang independen. Fenomenologi sebagai metode berdasarkan prinsip epoche dan penundaan penilaian dalam kaitan dengan pertanyaan tentang kebenaran fenomena keagamaan dan eidetic vitian yang merupakan pencarian esensi. Fenomenologi sebagai ilmu agama yang independen dibawa oleh Blekeer ke arah sejarah agamaagama karena menurutnya, kecil kemungkinan terjadi perbedaan pendapat mengenai sifat sejarah agama-agama. Tujuan sejarah agama adalah untuk mengkaji perkembangan historis agama-

46Waardenburgh, Reflection..., 304.

${ }^{47}$ Ibid., 367.

${ }^{48}$ Makalah ini adalah salah satu makalah yang mendapat tanggapan secara meluas dalam konferensi IAHR di Roma pada tahun 1969, 35-45. 
agama masa lalu maupun masa kini, terutama untuk agamaagama melalui berbagai sumber terutama teks-teks. ${ }^{49}$

Blekeer dengan pemaknaan yang berbeda antara fenomenologi sebagai sebuah metode dan ilmu agama independen membawa sebuah kesulitan ketika membahas sejarah sebagai sebuah metode sehingga ia menafikannya. Blekeer menganggap sejarah dalam dirinya sendiri hanya memainkan peran pembantu. ${ }^{50}$ Prinsip epoche dan eidetic vitian Blekeer dari Husserl yang dikembangkan melalui teori logos Van Der Leew kehilangan makna sejarah.

Dalam mencari hakekat agama menurut Martin, fenomenologi perlu metode pluralisme untuk mengkombinasikan berbagai pendekatan ilmu sejarah, bahasa, dan ilmu-ilmu sosial agar dapat menyinari fenomena agama dalam penelitian. Dalam tahap perkembangan ini, fenomenologi memerlukan karakter perbandingan dan ensiklopedik dari allgemene religionsgeschichte abad XIX, yang lebih mengupayakan perbandingan sederhana melalui sintesis makna-makna umum dan lintas sejarah.

Fenomenologi Model Mariasusai Dhavamony. Kesempatan lowong yang ditinggalkan Blekeer segera diisi oleh Mariasusai Dhavamony dengan konsep fenomenologi historis yang tertuang dalam buku Phenomenology of Religion. ${ }^{51}$ Fenomenologi historis bersifat empiris dalam arti membandingkan berbagai macam agama untuk menarik fakta dan fenomena yang sama. Pendapat Martin tentang fenomenologi pluralistik dalam jangkauan sosiologi antropologi dan psikologi pada hakekatnya mengambil makna Dhavamony. Menurut Dhavamony, meskipun fenomenologi agama berbeda dengan ilmu-ilmu lainnya. Seperti ilmu sosiologi, antropologi, dan psikologi yang mempelajari fenomena keagamaan yang sama, sejarah agama telah memperoleh manfaat dari penyelidikan-penyelidikan ilmu tersebut.

${ }^{49}$ Ibid., 366.

${ }^{50}$ Ibid., 357.

51 Buku yang dimaksud adalah karangan Mariasusai Dhavamony, Fenomenologi Agama, ter. Driyarkara (Yogyakarta: Kanisius, 1973). 
Dhavamony mendefinisikan fenomenologi historis agama adalah sebagai penyelidikan yang sistematis dari sejarah-sejarah agama yang bertugas mengkalsifikasikan dan mengelompokkan menurut cara tertentu terhadap sebuah data yang tersebar luas sehingga didapatkan suatu pandangan yang menyeluruh tentang isi agama dan makna religius yang dikandungnya. ${ }^{52}$ Dalam hal metodologi, Dhavamony sependapat dengan Blekeer, bahwa fenomenologi agama dipandang sebagai sebuah metode studi agama. Metode fenomenologi tidak sekadar semata-mata melakukan deskripsi terhadap fenomena yang dikaji, tetapi benar-benar memberikan makna yang dalam (inner meaning) dari suatu fenomena keagamaan sebagaimana yang dialami dan dijalani oleh para pengikutnya. Makna dalam ini juga dikatakan sebagai penyusun esensi fenomena tersebut. Esensi dipahami sebagai esensi empirik. Dhavamony menyebut fenomenologi agama sebagai ilmu empirik. ${ }^{53}$ Dengan demikian, Dhavamony masih tetap mempertahankan prinsip epoche untuk menyatakan keharusan objektivitas, dengan cara membiarkan fakta-fakta berbicara mengenai diri mereka sendiri. Menurutnya, epoche tidak dapat berurusan dengan dasar-dasar keyakinan keagamaan; prinsip eidetic vitian bertujuan untuk menangkap makna data-data keagamaan yang merupakan ekspresi dari pengalaman keagamaan dan keimanan batiniah.

Dhavamony merefleksikan fenomena keagamaan mencakup empati terhadap pengalaman, pemikiran, emosi, ide-ide dari orang lain, dan seterusnya. Empati memperlihatkan pemahaman terhadap tingkah laku orang lain berdasarkan pengalaman dan tingkah laku diri sendiri. Dengan demikian, pemahaman fenomena keagamaan bukanlah tindakan misterius atau mistik, juga bukan merupakan wawasan yang didasarkan pada kemampuan adikodrati untuk menembus pengalamanpengalaman orang lain. Lebih lanjut, Dhavamony menyebutkan dalam operasi pemahaman bukan sekadar menggunakan informasi tingkah laku sebagai sumber data, melainkan juga ciriciri psikologinya. Semakin besar koordinasi antara pengetahuan seseorang mengenai orang lain dan penggunaan kekayaan

\section{${ }^{52}$ Ibid., 26.}

53Waardenburgh, Reflection..., 361. 
pengalaman, makin dalam pemahaman kita terhadap orang lain. ${ }^{54}$

\section{Catatan Akhir}

Dari pembahasan di atas jelas bahwa pembahasan filsafat ilmu berkaitan dengan persoalan ontologi, epsitemologi, dan aksiologi, yakni berkaitan dengan hakekat objek kajian, bagaimana sebuah ilmu diperoleh dan bagaimana hasilnya dipergunakan. Hanya saja, apa yang disampaikan para filosof Barat dan Yunani tentang persoalan ontologis rupanya belum benar-benar menyentuh hakekat apa yang ada (being). Apa yang disampaikan aliran monisme, dualisme, maupun pluralisme baru pada tahap apa yang bisa dicapai oleh kekuatan rasio, tidak lebih dari itu. Ini mungkin dipengaruhi oleh sarana kajian yang lebih menggunakan rasio dan indera. Beberapa langkah ke depan justru telah dicapai oleh para filosof muslim masa pertengahan. Sayangnya, pencapaian mereka rupanya kurang mendapat banyak perhatian, baik oleh sarjana muslim sendiri, kecuali di kalangan madzhab Syi'ah, maupun Barat. Mereka telah membahas apa yang jauh di luar jangkauan nalar, seperti hakekat ketuhanan, hakekat sifat, hakekat waktu, proses perwujudan alam dari Tuhan yang Maha Ghaib, sampai pada alam kasat mata dan lain-lain, seperti yang dilakukan kaum sufi falsafi, semisal alJillî, Ibn 'Arabî, Ibn Sînâ, dan al-Farâbî.

Berangkat dari tingkat pemahaman ontologis yang tidak sama, terlihat epistemologi yang dilakukan juga berbeda. Para filosof Yunani dan Barat mengandalkan metode-metode rasional, penalaran induksi dan deduksi. Baru pada abad XIX dan XX ini, mereka mencoba metode baru, yaitu rasional kritis, fenomenologi Husserl, dan intuisi Bergson. Meskipun demikian, kita masih patut mempertanyakan apakah metode fenomenologi dan intuisi tersebut akan benar-benar mampu mencapai hakekat wujud, bahkan yang ghaib, mengingat Barat sampai saat ini rupanya masih mengesampingkan olah rohani (dalam pengertian Islam); persoalan ghaib adalah bagian rohani, bukan rasio. Para filosof muslim, untuk mencapai pengetahuan, sebagaimana

54Dhavamony, Fenomenologi..., 33. 
diuraikan di atas, menempuh jalan intuisi (tidak boleh disamakan dengan intuisi Bergson), tanpa mengabaikan metode-metode rasional. Dengan demikian, usaha-usaha ilmiah yang dilakukan mendapat cahaya dan bimbingan langsung dari Tuhan.

Dalam masalah aksiologi, rupanya ada kesepahaman antara pemikir Barat dan muslim; landasan utama adalah nilai-nilai kebaikan dan kemanfaatan manusia dan kemanusiaan. Hanya saja, dalam Islam, apa yang dinamakan kebaikan tidak hanya berdasarkan nilai-nilai moral an sich sebagaimana Barat, tetapi juga pemahaman keagamaan.

Terlepas dari perbedaan para filosof Barat dengan filosof Muslim tentang apa bidang garapan filsafat ilmu di atas, jelas bahwa filsafat ilmu memiliki kontribusi terhadap pengembangan penelitian/studi ilmu agama Islam. Dalam diskursus filsafat ilmu kontemporer, para filosof dan ilmuwan agama secara transparan menjelaskan kekurangan dan kelemahan konsepsi yang melekat dalam pandangan rasionalisme (sistem berpikir deduksi), empirisme (sistem berpikir induksi), logical positivism (percampuran antara logika deduksi dan induksi), dan begitu seterusnya. Aktivitas keilmuan agama tidak hanya didominasi oleh aspek logika keilmuan yang bersifat timeless essences dari aktivitas ilmuwan agama itu sendiri. Ilmu pengetahuan agama sesungguhnya syarat juga dengan beban muatan historis, cultural, dan sosiologis. Studi ilmu agama Islam dapat meniru jejak filsafat keilmuan dalam menatap dan menganalisis bangunan struktur keilmuan berbasis revolutionary science tanpa harus meninggalkan warisan, khazanah intelektual muslim klasik.

Studi ilmu agama Islam dalam artian kegiatan keilmuan sangatlah kaya nuansa sehingga rancang bangun keilmuannya dapat dikembangkan, disempurnakan, dan dirumuskan kembali sesuai dengan arus dan corak tantangan perubahan zaman yang selalu dialami manusia muslim itu sendiri. Dengan memanfaatkan filsafat ilmu dan metode keilmuan antropologi dalam wilayah studi ilmu agama Islam, manusia muslim akan diperkenalkan bagaimana sesungguhnya manusia muslim dalam wilayah ajaran (das sollen) dan dalam dataran senyatanya (das sein) sehingga memperoleh gambaran yang lebih utuh dan fundamental tentang fenomena keberagamaan manusia. 
Pendekatan fenomenologi yang diilhami oleh cara pendekatan filosofis yang dikembangkan Edmund Husserl dan filosof lainnya, berupaya untuk memperoleh esensi keberagamaan manusia. Pada titik inilah fenomenologi menjadi niscaya untuk kajian-kajian agama Islam. Paling tidak hal itu dapat digunakan untuk menutupi kekurangan model kajian yang cenderung menekankan formalisme agama yang hanya berhenti pada aspek-aspek luar (eksoteris). Pendekatan fenomenologi lebih juga bersifat value-laden (terikat oleh nilai-nilai keagamaan yang dipercayai dan dimiliki oleh para pengikut agama yang ada) dan berusaha memperoleh gambaran yang utuh serta struktur fundamental dari keberagamaan manusia secara umum (universal, transendental, dan inklusif). Dengan demikian, pendekatan fenomenologi mensyaratkan adanya empati agar tujuannya untuk mendapatkan gambaran yang utuh tentang keberagamaan manusia dapat dicapai.

\section{Daftar Pustaka}

A. Khudori Soleh, Pandangan Filosof Muslim terhadap Filsafat Ilmu (Makalah, t.t.).

A. Mukti Ali, dkk., Penelitian Agama di Indonesia (Jakarta: Sinar Harapan, 1982).

Al-Farâbî, “Al-Siyâsah al-Madâniyyah”, dalam Rasâil (Haiderabat: Dâr al-Ma'ârif al-'Utsmînî, 1345 H).

Al-Ghazâlî, Adab fî al- Dîn (Beirut: al-Maktabah al-Sya'biyah, t.t.). Al-Ghazâlî, I byâ' 'Ulûm al-Dîn I (Beirut: Dâr al-Fikr, t.t.).

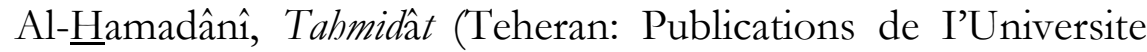
de Teheran, 1962).

Berling, dkk., Pengantar Filsafat Ilmu (Yogyakarta: Tiara Wacana, 1997).

C. Ver Haak, S.J. dan Hariyono Imam, Filsafat Ilmu Pengetahuan, Telaah atas Kerja Ilmu-Imu (Jakarta: PT. Gramedia, 1999).

Fazlur Rahman, Membuka Pintu Ijtihad, ter. Anas Mahyudin (Bandung: Pustaka, 1984).

Franz Magnis Susana, 13 Tokoh Etika Sejak Zaman Yunani sampai Abad ke-19 (Yogyakarta: Kanisius, 1997). 
Harold H. Titus, Persoalan-Persoalan Filsafat, ter. H.M. Rasjidi (Jakarta: Bulan Bintang, 1984).

Harold I. Brown, Perception, Theory and Commitment, the New of Philosophy Science (Chicago: The University of Chicago Press, 1972).

Harun Hadiwijono, Sari Sejarah Filsafat Barat II (Yogyakarta: Kanisius, 1997).

Joachim Wach, Ilmu Perbandingan Agama, ter. Djainonnuri (Jakarta: Rajawali, 1984).

Jujun S. Suriasumantri, Filsafat Ilmu: Sebuah Pengantar Populer (Jakarta: Sinar Harapan, 2006).

K. Bertens dan A.A. Nugroho, Panorama Filsafat Modern (Jakarta: Penerbit PT. Gramedia, 1987).

Kenneth T. Gallagher (Hartono Hadi), Epistemologi Filsafat Pengetabuan (Yogyakarta: Kanisius, 1987).

Koento Wibisono Siswomihardjo, Ilmu Pengetahuan Sebuah Sketsa Umum Mengenai Kelabiran dan Perkembangannya sebagai Pengantar untuk Memahami Filsafat Umum (Makalah disajikan pada Internship Filsafat Ilmu Pengetahuan Universitas Gadjahmada Yogyakarta bulan Januari 1997).

Louis O. Kattsoff, Pengantar Filsafat, ter. Soejono Soemargono (Yogyakarta: Tiara Wacana, 1996).

M. Amin Abdullah, Studi Agama, Normativitas atau Historisitas (Yogyakarta: Pustaka Pelajar, 1996).

Micea Aliade, The Sacred and The Profane: The Nature of Religion, ter.

Willard R. Trask (Harcourt: Brace \& World Inc., t.t.).

Osman Bakar, Classification of Knowledge in Islam, a Study in Islamic

Philosophies of Science (Kuala Lumpur: Institute for Policy Research, 1992).

Osman Bakar, Tawhid and Science, Essays on the History and Philosophy of Islamic Science (Malaysia: Secretariat for Islamic Philosophy and Science, 1991).

The Liang Gie, Pengantar Filsafat Ilmu (Yogyakarta: Liberty, 1997).

Thomas Kuhn, The Structure of Scientific Revolution (Chicago: The University of Chicago Press, 1976). 
Thomas Skluen, The Essential Tension: Selected Studies in Scientific Tradition and Change (Chicago: The University of Chicago Press, 1977).

Ver Haak dan Haryono Imam, Filsafat Ilmu Pengetabuan Telaah atas Cara Kerja Ilmu-ilmu (Jakarta: Gramedia, 1997).

Waardenburgh, Reflection on the Study of Religion: Dalam Metodologi Studi Agama, ter. Ahmad Norma Permata (Yogyakarta: Pustaka Pelajar, 2001). 